\title{
Application of advanced molecular techniques to detect vector borne pathogens from stray dogs and cats in two different climatic zones of Saudi Arabia
}

\author{
Abdullah D Alanazi ( $\square$ aalanazi@su.edu.sa ) \\ Shaqra University https://orcid.org/0000-0002-4862-7668 \\ Jan Šlapeta
}

The University of Sydney

Abulaziz Alouffi

King Abulaziz City For Science and Technology

Nichola Calvani

The University of Sydney

Mohamed Alyousif

King Saud University

Mohammad Alshahrani

King Khalid University

Ibrahim Alanazi

King AbulAziz City for Science and Technology

\section{Research}

Keywords: Anaplasma platys, Babesia vogeli, Bartonella henselae, MT-PCR, Mycoplasma canis, Saudi Arabia

Posted Date: April 7th, 2020

DOI: https://doi.org/10.21203/rs.3.rs-21131/v1

License: (a) (1) This work is licensed under a Creative Commons Attribution 4.0 International License. Read Full License 


\section{Abstract}

Background: Vector-borne diseases have been increasing worldwide and reported in many animals including dogs and cats. Limited or no data are currently available regarding canine and feline vectorborne diseases in Saudi Arabia and limited information is available from other Middle Eastern countries. The aim of this study was to compare vector-borne disease prevalence between two bio-climatically distinct regions of Saudi Arabia, Riyadh province that is arid positioned at low elevation and Asir province that is humid at high elevation.

Methods: Blood samples from 74d ogs from Riyadh province and 70 dogs and 44 cats from Asirprovince were collected and examined for the presence of genomic DNA of Babesias pp, Anaplasma spp., Ehrlichias pp., Bartonella spp., Mycoplasma spp., and Hepatozoon spp. by polymerase chain reaction (PCR), Multiplex-tandem PCR (MT-PCR) and Sanger sequencing.

Results: Seventy four dogs were tested from Riyadh province and found be negative of any pathogen. Of the 70 dogs examined from Asir province 45(64.3\%) were positive. Specifically, 40 (57.1\%) dogs were positive for A.platys, 20 (28.5\%) for B.vogeli, 11(15.7\%) for My.Haemocanis, two (2.85\%) for Candidatus Mycoplasma haematoparvum and one (1.4\%) for Br.henselae. Fourteen out of 44 cats $(31.8 \%)$ were positive for one of the detected vector-borne pathogens. Six cats (13.6\%) were positive for Candidatus Mycoplasma haemominutum and My.haemofelis, respectively, four cats (9.2\%) were positive for Br.Henselae, two (4.54\%) for Candidatus Mycoplasma haematoparvum and one (2.27\%) for A. platys.

Conclusions: The results of this study report the occurrence of $A$. platys, B. vogeli, Br. henselae, and $M y$. haemocanis in dogs and of A. platys, Br. henselae, My.haemofelis and Candidatus Mycoplasma haemominutum in cats from Asir province Further molecular investigations are strongly recommended in order to reduce the risk of dogs and cats acquiring vector-borne diseases in Saudi Arabia.

\section{Introduction}

Arthropods such as ticks, fleas and mosquitoes are globally important vectors of a wide range of viral, bacterial and protozoal pathogens resulting in a variety of animal diseases [1, 2]. In some cases, vectorborne diseases are zoonotic and a direct threat to human health and animal welfare $[3,4]$. Other effects of arthropods feeding include anaemia, paralysis, immuno-suppression and invasion of tick bite wounds by secondary bacterial pathogens. Vector-borne diseases are often widespread in tropical and subtropical regions, including in the Middle East, due to optimal climatic conditions for vectors such as ticks, fleas and mosquitoes [5]. Tick infestations of dogs and cats are common in Saudi Arabia and mainly involves Hyalomma dromedarii (Koch, 1844) and Rhipicephalus sanguineus sensulato (s.l.)(Latreille, 1806) [6, 7], which is a competentvector of diseases such as anaplasmosis, babesiosis, ehrlichiosis, hepatozoonosis and different Rickettsia species, among others [8].

The prevalence of vector-borne disease in a population closely reflects the distribution and density of such vectors $[9,10]$. Vector-borne disease in dogs and cats can be caused by rickettsial parasites (e.g. 
Anaplasma, Rickettsia) and haemoplasmas species (e.g. Mycoplasma haemofelis, Mycoplasma haematoparvum), resulting in potentially fatal and often persistent infections [10,11, 12]. Studies in countries situated in and around the Middle Eastreport the presence of vector-borne pathogens including Anaplasma platys, Ehrlichia canis, Bartonella spp.,and Babesia spp. in dogs and cats $[9,13,14,15,16,17$, $18,19]$.Currently, limited studies have examined the presence of vector-borne disease in dogs and cats in Saudi Arabia $[7,20,21,22,23]$. Therefore, the aim of this study was to evaluate the presence of vectorborne pathogens in dogs and cats in two different climatic zones of Saudi Arabia using a commercial diagnostic MT-PCR panel for the detection of Babesia gibsoni, Babesia vogeli, Mycoplasma haematoparvum, Mycoplasma haemocanis, Mycoplasma haemofelis, Anaplasma platys and Bartonella species.

\section{Methods And Materials}

\subsection{Ethical approval}

This study was revised and approved by the Ethical Research Committee, Department of Biological Science, Shaqra University, according to the ethical principles of human and animal research (Approval no. SH 06-2018).

\subsection{Study areas}

The investigation was conducted from November 2018 to August 2019 in two provinces of Saudi Arabia.The Riyadh province of Saudi Arabia has an area of $404,240 \mathrm{~km}^{2}$ and is located in the central part of Saudi Arabia between $24^{\circ} .38^{\circ} \mathrm{N}$ and $46^{\circ} .43^{\circ} \mathrm{E}$ (Figure 1). This province is characterised by very hot summers with an average high temperature of $45^{\circ} \mathrm{C}$ in July. Winters are cold, the overall climate is arid, receiving very little annual rainfall $(21.4 \mathrm{~mm})$, with the relative humidity ranging from $10 \%$ to $47 \%$ throughout the year. Riyadh province is also known to have many dust storms (http://www.pme.gov.sa). Asir province, has an area of $76,690 \mathrm{~km}^{2}$ and is located in the southwestern part of Saudi Arabia between $19^{\circ} 0^{\prime} \mathrm{N}$ and $43^{\circ} 0^{\prime} \mathrm{E}$ (Figure 1). Asir province is situated on a high plateau that receives more rainfall than the rest of the country and contains the country's highest peaks, which rise to almost 3,000 m. Asir has a tropical and subtropical climate and the average annual rainfall in the highlands is expected torange from 300 to $500 \mathrm{ml}$ across two rainy seasons. As a result, there is much more natural vegetation and forests (http://www.pme.gov.sa).

\subsection{Sampling of dogs and cats and blood collections}

Stray dogs and cats from the two provinces were trapped by a live bait traps (Havahart ${ }^{\circledR}$ ) and selected randomly.A total of 74 dogs from Riyadh province (48 males and 26 females) and a total of 70 dogs and 44 cats from Asir province (dogs; 43 males and 27 females, cats; 30, male and 14 females). Dogs and cats varied in ages from $\leq 6$ months to $>6$ months and were examined forhaemoparasites. Most of the dogs and cats appeared healthy at the time of blood collection. Blood samples were collected from each animal $(0.5-3 \mathrm{ml})$ from the cephalic vein into vacutainer tubes (BD Vacutainer® Tube, Gribbles 
Pathology, VIC, Australia) and transported to the parasitology laboratory, Department of Biological Sciences, Faculty of Science and Humanities, Shaqra University, for DNA extraction.

\subsection{DNA extraction}

Total genomic DNA (gDNA) was isolated from the blood samples using the Wizard® Genomic DNA Purification Kit (Promega, Madison,WI, USA) and eluted into $50 \mu \mathrm{l}$ or $100 \mu \mathrm{l}$ of elution buffer as per the manufacturer's instruction. An aliquot between $50 \mu \mathrm{l}$ and $100 \mu \mathrm{l}$ of gDNA from each of the samples was stored at $-80^{\circ} \mathrm{C}$ prior to being sent to Veterinary Pathology Diagnostic Services (VPDS), Sydney School of Veterinary Science, The University of Sydney for PCR analysis. Upon arrival atVPDS gDNA was stored at $-20^{\circ} \mathrm{C}$ for up to 1 month prior to molecular diagnostics.

\subsection{Commercial Multiplexed Tandem PCR (MT-PCR) for Small Animal Anaemia}

A commercial diagnostic MT-PCR panel for small animal anaemia was performed using the mini-plex 12 system (R910738, AusDiagnostics Pty. Ltd., Australia) as per the manufacturers' instruction. The MT-PCR assay is a two-step nested PCR assay simultaneously targeting B. gibsoni, B. vogeli, M. haematoparvum, M. Haemocanis and A. platys and was run on the Easy-Plex ${ }^{\mathrm{TM}}$ platform (AusDiagnostics Pty. Ltd., Australia). The assay was run in duplicate using $10 \mu$ lundiluted samples ( $n=188)$. Each run included controls to detect PCR inhibition (SPIKE) and sample adequacy control (ANONO) as per the manufacturers' protocol (AusDiagnostics Pty. Ltd., Australia).

The positive samples were tested using 16S rRNA primers (S0697/S0698) for Anaplasma platys [24], 18S rRNA primers (S0701/S0702) for the universal amplification of Mycoplasma spp. [25] and 18S rRNA primers for Babesia spp.[26]. All PCR reactions were run using MyTaq ${ }^{\text {TM}}{ }_{\text {RedMix (Bioline, Australia) in a }}$ Veriti Thermal Cycler (Life Sciences, Australia). Primers were included at a final concentration of 400nM/ $\mu \mathrm{l}$ and $2 \mu \mathrm{l}$ of template DNA was used per reaction. All non-nested PCR were run using the following cycling conditions: $95^{\circ} \mathrm{C}$ for $1 \mathrm{~min}$ and 35 cycles of $95^{\circ} \mathrm{C}$ for $15 \mathrm{~s}, 50^{\circ} \mathrm{C}$ for $15 \mathrm{~s}$ and $72{ }^{\circ} \mathrm{C}$ for $10 \mathrm{~s}$ followed by $72^{\circ} \mathrm{C}$ for $5 \mathrm{~min}$. PCR reactions with Babgen-F/Babgen-R primers were run with an annealing temperature of $55^{\circ} \mathrm{C}$, and all other conditions as previously described. The first round of the nested PCR was run using the following cycling conditions: $95^{\circ} \mathrm{C}$ for $1 \mathrm{~min}$ and 35 cycles of $95^{\circ} \mathrm{C}$ for $15 \mathrm{~s}, 55^{\circ} \mathrm{C}$ for $15 \mathrm{~s}$ and $72{ }^{\circ} \mathrm{C}$ for $10 \mathrm{~s}$ followed by $72{ }^{\circ} \mathrm{C}$ for $5 \mathrm{~min}$. The second round of the nested PCR was run using a $60{ }^{\circ} \mathrm{C}$ annealing temperature with all other conditions as described for the first round. A negative and positive control was included in all assays. All PCR products were separated by electrophoresis in $2 \%$ agarose gel stained with GelRed ${ }^{\mathrm{TM}}$ (Biotium, USA) and visualised using UV light. Discrete bands of expected size were submitted for bidirectional sequencing using amplification primers (Macrogen, South Korea). Sequences were assembled and compared to closely related sequences using CLC Main Workbench 6.8.1 (CLC bio, Denmark).

\subsection{Real-time PCR: Bartonella spp.}


A multiplex TaqMan probe real time PCR assay targeting the gltAgene of Rickettsia spp. was multiplexed with an assay targeting the ssrA gene of Bartonella spp. [27, 28, 29]. PCR reactions were run using

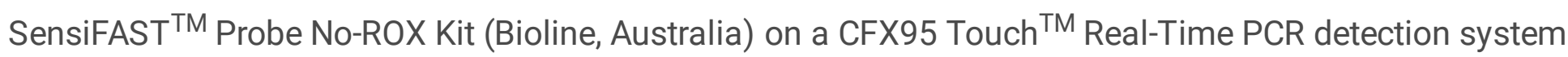
(BioRad Laboratories Inc., Australia).

\subsection{Statistical analysis}

Statistical analyses were performed with the statistics package SPSS (v.17.0; IBM, New York, New York). Positive PCR test was set as an outcome variable and the independent variables were age, gender and, health status. The effect of independent variables on the outcome variables were evaluated by chi-square and Fisher's exact test and Odds Ratio (OR) calculation. Differences were considered significant if the $P$ value was $<0.05$.

\section{Results}

All of the 74 dogs tested from Riyadh province were negativeforall testedpathogens, while 45 of 70 (64.3\%) dogs examined from Asir province were positive. Forty (57.1\%) dogs were positive for Anaplasmaplatys, 20(28.5\%) for Babesia vogeli, 11(15.7\%) for Mycoplasma haemocanis, two (2.85\%) for Candidatus Mycoplasma haematoparvum and one (1.4\%) for Bartonella henselae. Animals co-infected with more than onepathogens (i.e. A.platys and B. vogeli) were molecularly detected in this study (Table 1).

Table 1: Prevalence, accession number and percentage of nucleotide identity of vector-borne pathogens detected in dogs and cats from Riyadh province and Asir province, Saudi Arabia.

\begin{tabular}{|c|c|c|c|c|}
\hline \multirow[t]{2}{*}{ Pathogen } & $\begin{array}{c}\text { Riyadh } \\
\text { Province }\end{array}$ & \multicolumn{2}{|c|}{ Asir Province } & $\begin{array}{l}\text { Accession number, } \\
\text { percentage } \\
\quad \text { of nucleotide } \\
\text { identity }\end{array}$ \\
\hline & Dogs $(n=74)$ & $\begin{array}{c}\text { Dogs } \\
(n=70)\end{array}$ & $\begin{array}{c}\text { Cats } \\
(n=44)\end{array}$ & \\
\hline Anaplasma platys & $0(0.00 \%)$ & $\begin{array}{c}40 \\
(57.1 \%) \\
\end{array}$ & $1(2.27 \%)$ & KU500911, 99.85\% \\
\hline Babesia vogeli & $0(0.00 \%)$ & $\begin{array}{c}20 \\
(28.5 \%) \\
\end{array}$ & $0(0.00 \%)$ & AY371198, 99,27\% \\
\hline Bartonella henselae & $0(0.00 \%)$ & $1(1.4 \%)$ & $4(9.2 \%)$ & MF105891.1, 98\% \\
\hline $\begin{array}{l}\text { *Haemofelis } \\
\text { /Haemocanis }\end{array}$ & $0(0.00 \%)$ & $\begin{array}{c}11 \\
(15.7 \%)\end{array}$ & $\begin{array}{c}6 \\
(13.63 \%)\end{array}$ & MN294708, 100\% \\
\hline Bartonella henselae & $0(0.00 \%)$ & $2(2.85 \%)$ & $2(4.54 \%)$ & MF105891.1, 98\% \\
\hline Haemominutum & $0(0.00 \%)$ & $0(0.00 \%)$ & $\begin{array}{c}6 \\
(13.63 \%)\end{array}$ & ns \\
\hline
\end{tabular}

ns, not sequenced, * =Mycoplasma haemocanis was sequenced from dogs 
Fourteen out of 44 cats (31.8\%) were positive for one of the detected vector-borne pathogens. Six cats (13.6\%) were positive for Candidatus Mycoplasma haemominutum and Candidatus Mycoplasma haemofelis, respectively. Four cats (9.2\%) were positive for Bartonella henselae, two (4.54\%) for Candidatus Mycoplasma haematoparvum and one for (2.27\%) Anaplasma platys (Table 1). BLAST analysis confirmed the pathogen identification with the highest nucleotide identity (i.e. $98-100 \%$, Tables 1) with the sequences available in the GenBank database (accession numbers: KU500911; AY371198; MF105891.1; MN294708). No animals were positive for other haemoparasites. No statistically significant associations were found for positivity to canine and feline vector-borne diseases among the categories of age, gender and health status (Table 2).

Table 2: Characteristics of heamoparasites- PCR negative and PCR-positive of stray dogs and cats in Asir Provinces, Saudi Arabia.

\begin{tabular}{|c|c|c|c|c|c|c|}
\hline \multirow[t]{3}{*}{ Variables } & \multicolumn{5}{|c|}{ Asir Province } & \multirow[b]{3}{*}{$P$-value } \\
\hline & \multicolumn{2}{|c|}{ Dogs $(n=70)$} & & \multicolumn{2}{|c|}{ Cats $(n=44)$} & \\
\hline & $\begin{array}{c}\text { PCR } \\
\text { Negative } \\
\%\end{array}$ & $\begin{array}{c}\text { PCR } \\
\text { Positive } \\
(\%)\end{array}$ & $P$-value & $\begin{array}{c}\text { PCR } \\
\text { Negative } \\
\%\end{array}$ & $\begin{array}{c}\text { PCR } \\
\text { Positive } \\
(\%)\end{array}$ & \\
\hline \multicolumn{7}{|l|}{ Age } \\
\hline $\begin{array}{l}\text { Juvenile } \\
(\leq 6 \text { months })\end{array}$ & $8(11.4 \%)$ & $13(18.6 \%)$ & 0.177344 & $\begin{array}{c}9 \\
(20.5 \%)\end{array}$ & $1(2.3 \%)$ & 0.123291 \\
\hline$(>6 \text { months })^{\text {Adult }}$ & $\begin{array}{c}11 \\
(15.7 \%)\end{array}$ & $38(54.3 \%)$ & & $\begin{array}{c}22 \\
(50.0 \%)\end{array}$ & $\begin{array}{c}12 \\
(27.3 \%)\end{array}$ & \\
\hline \multicolumn{7}{|l|}{ Gender } \\
\hline Male & 9 (12.8\%) & $34(48.6 \%)$ & 0.140194 & $\begin{array}{c}9 \\
(20.5 \%)\end{array}$ & $\begin{array}{c}21 \\
(47.7 \%)\end{array}$ & 0.922934 \\
\hline Female & $\begin{array}{c}10 \\
(14.3 \%)\end{array}$ & $17(24.3 \%)$ & & $4(9.1 \%)$ & $\begin{array}{c}10 \\
(22.7 \%)\end{array}$ & \\
\hline \multicolumn{7}{|l|}{ Health status } \\
\hline Apparently healthy & $\begin{array}{c}18 \\
(25.7 \%)\end{array}$ & $45(45.0 \%)$ & 0.420057 & $\begin{array}{c}28 \\
(63.6 \%)\end{array}$ & $\begin{array}{c}11 \\
(25.0 \%)\end{array}$ & 0.586282 \\
\hline Symptomatic & $1(1.43 \%)$ & $6(8.6 \%)$ & & $3(6.8 \%)$ & $2(4.6 \%)$ & \\
\hline
\end{tabular}

\section{Discussion}

The results of this study demonstrate that dogs and cats from Saudi Arabia, are infected with several canine and feline vector-borne diseases, which have been identified by sequence analysis. Although, the sample size of dogs and cats in the current studywas small, the occurrence of A. platy, B. vogeli, My. haemocanis, Br. Henselae and Candidatus Mycoplasma haematoparvum have been recorded in dogs from Asir Province andA. platy, Br. henselae, Candidatus Mycoplasma haemominutum and My.haemofelis and Candidatus Mycoplasma haematoparvumin cats. No infection among dogs was recorded from Riyadh province and this could be attributed by a low prevalence or absence of Rhipicephalus sanguineus in dogs in Riyadh province which is the main vector for canine and feline borne diseases [7]. 
Limited data is available on the status of hemoplasmas in the Middle East, with two studies showing the presence of the two feline species Candidatus Mycoplasma haemofelis and Candidatus Mycoplasma haemominutum detected in cats from Qatar [30] and three feline species My. haemofelis, My.Haemominutum and My.turicensis in Iranian cats [31]. In the present study, Candidatus Mycoplasma haemominutum, My.haemofelis and Candidatus Mycoplasma haematoparvum in cats were detected in and My.haemocanis and Candidatus Mycoplasma haematoparvum were found in dogs cats from Asir province. The presence of $B r$. Henselae has been previously reported seroprevalence in the Middle East region $[32,33,34]$. To our knowledge, this the first molecular study reporting $A$. platys in cats from Saudi Arabia and other Middle Eastern countries.

The occurrence of A. platys, B.vogeli and Br. Henselae in dogs has been previously reported in the Middle East $[9,19,30]$. The present study provides the first molecular evidence of My.haemocanis, and Candidatus Mycoplasma haematoparvum from dogs in Saudi Arabia. These parasites have previously been recorded in dogs from Qatar [30] and Iran [35].

Most of the detected pathogens are vectored by Rhipicephalus sanguineus (s.l), a tick species displaying a worldwide geographical distribution $[7,36]$. Rh. sanguineus can infest a wide range of domestic and wild animals, including dogs, cats, rodents and birds [37]. Parasitism of $R h$. sanguineus on hosts other than dogs is quite unusual in several regions [38]. Rh. sanguineus has been reported in low prevalence in domestic and wild animals including dogs and cats fromcentral parts of Saudi Arabia [6, 39, 40], along with western and southern Saudi Arabia [41, 42, 43]. The climate of Saudi Arabia has shown to be potentially suitable to the perpetuation of vectors and transmission of several arthropod-borne diseases $[44,45]$. Indeed the environmental conditions of Saudi Arabia aresuitablefor the development of different tick species due to wide range of climatic conditions [46]. Climate conditions, animals diversity and vegetations vary and are different between Riyadh province and Asir province. Riyadh province is arid and positioned at low elevation, while Asir province is humid at a higher elevation. It has been shown that $R h$. sanguineus can develop well under different conditions in terms of temperature (e.g., 20-35 $\mathrm{C}$ ) and relative humidity (e.g., 35-95\%) [47]. In a previous study Chandra et al., (2019) have shown that $H$. Dromedarii is the most common tick parasitising dogs in Riyadh province.This tick preferentially parasitises camels, although has been known to parasitise other ungulates [48, 49]. In this study, we did not collected ticks from dogs and cats from Asir province hence it is difficult to conclude the presence of these parasites in Asir province but not in Riyadh province.

\section{Conclusion}

This study expands existing information on the distribution of canine and feline vector-borne diseases in dogs and cats inhabiting Saudi Arabia. Further studies, including a larger number of animal hostsand populations from other provinces of Saudi Arabia are requiredto better understand the epidemiological distributions of canine and feline vector-borne diseases in the country. Our adoption of a multiplextandem PCR assay with internal controls is shown to be a suitable platform for the detection of canine 
and feline vector-borne pathogens. Despite the small number of examined dogs and catsfrom Saudi Arabia the approach is suitable for baseline prevalence evaluation.

\section{Declarations}

\section{Disclosure}

The authors declare that they have no competing interests.

\section{Funding}

Not applicable.

\section{Consent for publication}

Not applicable.

\section{Ethics approval and consent to participate}

Blood sampling for this study was approved by the Ethical Research Committee, Shaqra University and complied with relevant guidelines for animal handling and welfare (Approval no. SH 06-2018)

\section{Authors' contributions}

ADA and JŠ participated in the study design. MSA coordinated, ASA,IOA and MAY collected ticks and blood samples and performed blood DNA isolation. NEDCand JŠ performed MT-PCR, PCR and qPCR. ADA, NEDC and JŠ interpreted the PCR results. ADA and JŠ wrote the manuscript. All authors read and approved the final manuscript.

\section{Acknowledgements}

This study was kindly supported by Shaqra University, Deanship of Scientific Research. The authors would like to thank the Staff Members of Biological Science Department, Faculty of Science and Humanities, Shaqra University and the staff members of the Department of Veterinary Parasitology, School of Veterinary Sciences, The University of Sydney for kind technical support

\section{Availability of data and material}

Detailed summary of diagnostic assays outcomes is available in Supplementary Table S1.

\section{References}

1. Otranto D, Dantas-Torres F. Canine and feline vector-borne diseases in Italy: current situation and perspectives. Parasites Vectors 2010;3 1:2; doi:. https://doi.org/10.1186/1756-3305-3-2. 
2. Mylonakis ME, Schreeg M, Chatzis MK, Pearce J, Marr HS, Saridom ichelakis MN, et al. Molecular detection of vector-borne pathogens in Greek cats. Ticks Ttick-Borne Diseases. 2018;9(2):171-5.

3. 10.1016/j.cimid.2012.08.001

Yuasa Y, Hsu T-H, Chou C-C, Huang C-C, Huang W-C, Chang C-C. The comparison of spatial variation and risk factors between mosquito-borne and tick-borne diseases: Seroepidemiology of Ehrlichia canis, Anaplasma species, and Dirofilaria immitis in dogs. Comparative Immunology, Microbiology and Infectious Diseases. 2012;35 6:599-606; doi: .

4. de La Fuente J, Antunes S, Bonnet S, Cabezas-Cruz A, Domingos AG, Estrada-Peña A, et al. Tickpathogen interactions and vector competence: identification of molecular drivers for tick-borne diseases. Frontiers in Cellular Infection Microbiology. 2017;7:114.

5. Kilpatrick AM, Randolph SE. Drivers, dynamics, and control of emerging vector-borne zoonotic diseases. The Lancet. 2012;380:9857:1946-55.

6. Alanazi AD, Al-Mohammed HI, Alyousif MS, Said AE, Salim B, Abdel-Shafy S, et al. Species Diversity and Seasonal Distribution of Hard Ticks (Acari: Ixodidae) Infesting Mammalian Hosts in Various Districts of Riyadh Province, Saudi Arabia. J Med Entomol. 2019;56 4:1027-32.

7. Chandra S, Smith K, Alanazi AD, Alyousif MS, Emery D, Šlapeta J. Rhipicephalus sanguineus sensu lato from dogs and dromedary camels in Riyadh, Saudi Arabia: low prevalence of vector-borne pathogens in dogs detected using multiplexed tandem PCR panel. Folia Parasitol. 2019;66:1-13.

8. Otranto D, Dantas-Torres F, Breitschwerdt EB. Managing canine vector-borne diseases of zoonotic concern: part one. Trends in Parasitology. 2009;25:4:157-63.

9. Aktas M, Ozubek S, Altay K, Ipek ND, Balkaya I, Utuk AE, et al. Molecular detection of tick-borne rickettsial and protozoan pathogens in domestic dogs from Turkey. Parasites Vectors. 2015;8:157.

10. Vascellari M, Ravagnan S, Carminato A, Cazzin S, Carli E, Da Rold G, et al. Exposure to vector-borne pathogens in candidate blood donor and free-roaming dogs of northeast Italy. Parasites Vectors. 2016;9(1):369.

11. Hii SF, Traub RJ, Thompson MF, Henning J, O'Leary CA, Burleigh A, et al. Canine tick-borne pathogens and associated risk factors in dogs presenting with and without clinical signs consistent with tickborne diseases in northern Australia. Aust Vet J. 2015;93 3:58-66.

12. André MR, Baccarim Denardi NC, Marques de Sousa KC, Gonçalves LR, Henrique PC, Grosse Rossi Ontivero CR, et al. Arthropod-borne pathogens circulating in free-roaming domestic cats in a zoo environment in Brazil. Ticks Tick-borne Diseases. 2014;5:5:545-51.

13. $10.1017 / \mathrm{s} 0031182016002201$

Azmi K, Al-Jawabreh A, Nasereddin A, Abdelkader A, Zaid T, Ereqat S, et al. Detection and molecular identification of Hepatozoon canis and Babesia vogeli from domestic dogs in Palestine. Parasitology. 2016:1-9; doi: .

14. Baneth G, Breitschwerdt EB, Hegarty BC, Pappalardo B, Ryan J. A survey of tick-borne bacteria and protozoa in naturally exposed dogs from Israel. Vet Parasitol. 1998;74:2-4:133 - 42. 
15. Nazari M, Lim SY, Watanabe M, Sharma RS, Cheng NA, Watanabe M. Molecular detection of Ehrlichia canis in dogs in Malaysia. PLoS Neglected Tropical Diseases. 2013;7:1:e1982.

16. Mazaheri Nezhad Fard R, Vahedi SM, Ashrafi I, Alipour F, Sharafi G, Akbarein H, et al. Molecular identification and phylogenic analysis of Bartonella henselae isolated from Iranian cats based on gltA gene. Veterinary Research Forum. 2016;7(1):69-72.

17. Torkan S, Aldavood SJ, Sekhavatmandi A, Moshkelani S. Detection of haemotropic Mycoplasma (Haemobartonella) using multiplex PCR and its relationship with epidemiological factors in dogs. Comp Clin Pathol. 2014;23:3:669-72.

18. Aktas M, Ozubek S. A molecular survey of hemoplasmas in domestic dogs from Turkey. Vet Microbiol. 2018;221:94-7.

19. Greco G, Sazmand A, Goudarztalejerdi A, Zolhavarieh S, Decaro N, Lapsley W, et al. High Prevalence of Bartonella sp. in Dogs from Hamadan, Iran. The American Journal of Tropical Medicine Hygiene. 2019. doi:.

20. Alanazi AD. Parasitological and Molecular Detection of Canine Trypanosomiasis From Riyadh Province, Saudi Arabia. Journal of Parasitology. 2018;104:5:539-43.

21. Salim B, Alanazi AD, Omori R, Alyousif MS, Alanazi IO, Katakura K, et al. Potential role of dogs as sentinels and reservoirs for piroplasms infecting equine and cattle in Riyadh City, Saudi Arabia. Acta Trop. 2019;193:78-83.

22. Rees DJ, Dioli M, Kirkendall LR. Molecules and morphology: evidence for cryptic hybridization in African Hyalomma (Acari: Ixodidae). Mol Phylogenet Evol. 2003;27:1:131-42.

23. Sacchini F, Cessford RJ, Robinson BM. Outbreak of canine monocytic ehrlichiosis in Saudi Arabia. Veterinary clinical pathology. 2007;364:331-5.

24. Harrus S, Perlman-Avrahami A, Mumcuoglu K, Morick D, Eyal O, Baneth G. Molecular detection of Ehrlichia canis, Anaplasma bovis, Anaplasma platys, Candidatus Midichloria mitochondrii and Babesia canis vogeli in ticks from Israel. Clinical Microbiology and Infection. 2011;17 3:459 - 63.

25. Criado-Fornelio A, Martinez-Marcos A, Buling-Sarana A, Barba-Carretero J. Presence of Mycoplasma haemofelis, Mycoplasma haemominutum and piroplasmids in cats from southern Europe: a molecular study. Vet Microbiol. 2003;93(4):307-17.

26. Olmeda A, Armstrong P, Rosenthal B, Valladares B, Del Castillo A, De Armas F, et al. A subtropical case of human babesiosis. Acta Trop. 1997;67:3:229-34.

27. Santos F, Coppede JS, Pereira AL, Oliveira LP, Roberto PG, Benedetti RB, et al. Molecular evaluation of the incidence of Ehrlichia canis, Anaplasma platys and Babesia spp. in dogs from Ribeirão Preto, Brazil. Vet J. 2009;179(1):145-8.

28. Šlapeta Š, Šlapeta J. Molecular identity of cat fleas (Ctenocephalides felis) from cats in Georgia, USA carrying Bartonella clarridgeiae, Bartonella henselae and Rickettsia sp. RF2125. Veterinary Parasitology: Regional Studies Reports. 2016;3:36-40.

29. Diaz MH, Bai Y, Malania L, Winchell JM, Kosoy MY. Development of a novel genus-specific real-time PCR assay for detection and differentiation of Bartonella species and genotypes. J Clin Microbiol. 
2012;50 5:1645-9.

30. Alho AM, Lima C, Latrofa MS, Colella V, Ravagnan S, Capelli G, et al. Molecular detection of vectorborne pathogens in dogs and cats from Qatar. Parasites Vectors. 2017;10 1:298.

31. Ghazisaeedi F, Atyabi N, Zahrai Salehi T, Gentilini F, Ashrafi Tamai I, Akbarein H, et al. A molecular study of hemotropic mycoplasmas (hemoplasmas) in cats in Iran. Vet Clin Pathol. 2014;43(3):3816.

32. Celebi B, Kilic S, Aydin N, Tarhan G, Carhan A, Babur C. Investigation of Bartonella henselae in cats in Ankara, Turkey. Zoonoses Public Health. 2009;56(4):169-75.

33. Oskouizadeh K, Zahraei-Salehi T, Aledavood S. Detection of Bartonella henselae in domestic cats' saliva. Iranian Journal of Microbiology. 2010;2 2:80.

34. Gutiérrez R, Morick D, Gross I, Winkler R, Abdeen Z, Harrus S. Bartonellae in domestic and stray cats from Israel: comparison of bacterial cultures and high-resolution melt real-time PCR as diagnostic methods. Vector-Borne Zoonotic Diseases. 2013;13 12:857-64.

35. Hosseini SR, Sekhavatmandi A, Khamesipour F. PCR based analysis of Haemobartonellosis (Candidatus mycoplasma haematoparvum and Mycoplacma haemocanis) and its prevalence in dogs in Isfahan, Iran. Bioscience Biotechnology Research Communications. 2017;10(2):187-91.

36. Dantas-Torres F, Latrofa MS, Annoscia G, Giannelli A, Parisi A, Otranto D. Morphological and genetic diversity of Rhipicephalus sanguineus sensu lato from the New and Old Worlds. Parasites Vectors. 2013;6 1:213.

37. Walker JB, Keirans JE, Horak IG. The genus Rhipicephalus (Acari, Ixodidae): a guide to the brown ticks of the world. Cambridge University Press; 2005.

38. Dantas-Torres F. Biology and ecology of the brown dog tick, Rhipicephalus sanguineus. Parasites Vectors. 2010;3(1):26.

39. Asiry KA, Fetoh BE-SA. Occurrence of ectoparasitic arthropods associated with rodents in Hail region northern Saudi Arabia. Environ Sci Pollut Res. 2014;21 17:10120-8.

40. Al-Khalifa M, Diab F. A checklist of ticks (Acari: Ixodidae) infesting local farm animals in Saudi Arabia. II. Ticks of Riyadh province. J Coll Sci King Saud Univ. 1986;17:151-7.

41. Al-Khalifa M, Hussein H, Al-Asgah N, Diab F. Ticks. (Acari: Ixodidae) infesting local domestic animals in western and southern Saudi Arabia. Arab Gulf J Sci Res B. 1987;5:301-19.

42. Harrison A, Robb GN, Alagaili A, Hastriter M, Apanaskevich D, Ueckermann E, et al. Ectoparasite fauna of rodents collected from two wildlife research centres in Saudi Arabia with discussion on the implications for disease transmission. Acta Trop. 2015;147:1-5.

43. Al-Mohammed H. Taxonomical studies of ticks infesting wild rodents from Asir Province in Saudi Arabia. J Egypt Soc Parasitol. 2008;38(1):1-8.

44. Alanazi AD, Abdullah S, Helps C, Wall R, Puschendorf R, ALHarbi SA, et al. Tick-Borne Pathogens in Ticks and Blood Samples Collected from Camels in Riyadh Province, Saudi Arabia. Zoological Research. 2018;14:1:30-6. 
45. Alanazi AD, Nguyen VL, Alyousif MS, Manoj RR, Alouffı AS, Donato R, et al. Ticks and associated pathogens in camels (Camelus dromedarius) from Riyadh Province, Saudi Arabia. Parasites Vectors. 2020;13 1:1-9.

46. Hoogstraal H, Wassef H, Büttiker W. Ticks (Acarina) of Saudi Arabia. Fam. Argasidae, Ixodidae. Fauna of Saudi Arabia. 1981;3:25-110.

47. Koch HG, Tuck MD. Molting and survival of the brown dog tick (Acari: Ixodidae) under different temperatures and humidities. Ann Entomol Soc Am. 1986;79(1):11-4.

48. Apanaskevich DA, Horak IG. The genus Hyalomma. XI. Redescription of all parasitic stages of H. (Euhyalomma) asiaticum (Acari: Ixodidae) and notes on its biology. Exp Appl Acarol. 2010;52(2):207-20.

49. EIGhali A, Hassan S. Life cycle of the camel tick Hyalomma dromedarii (Acari: Ixodidae) under field conditions in Northern Sudan. Veterinary Parasitology. 2010;174:3-4:305 - 12.

\section{Figures}

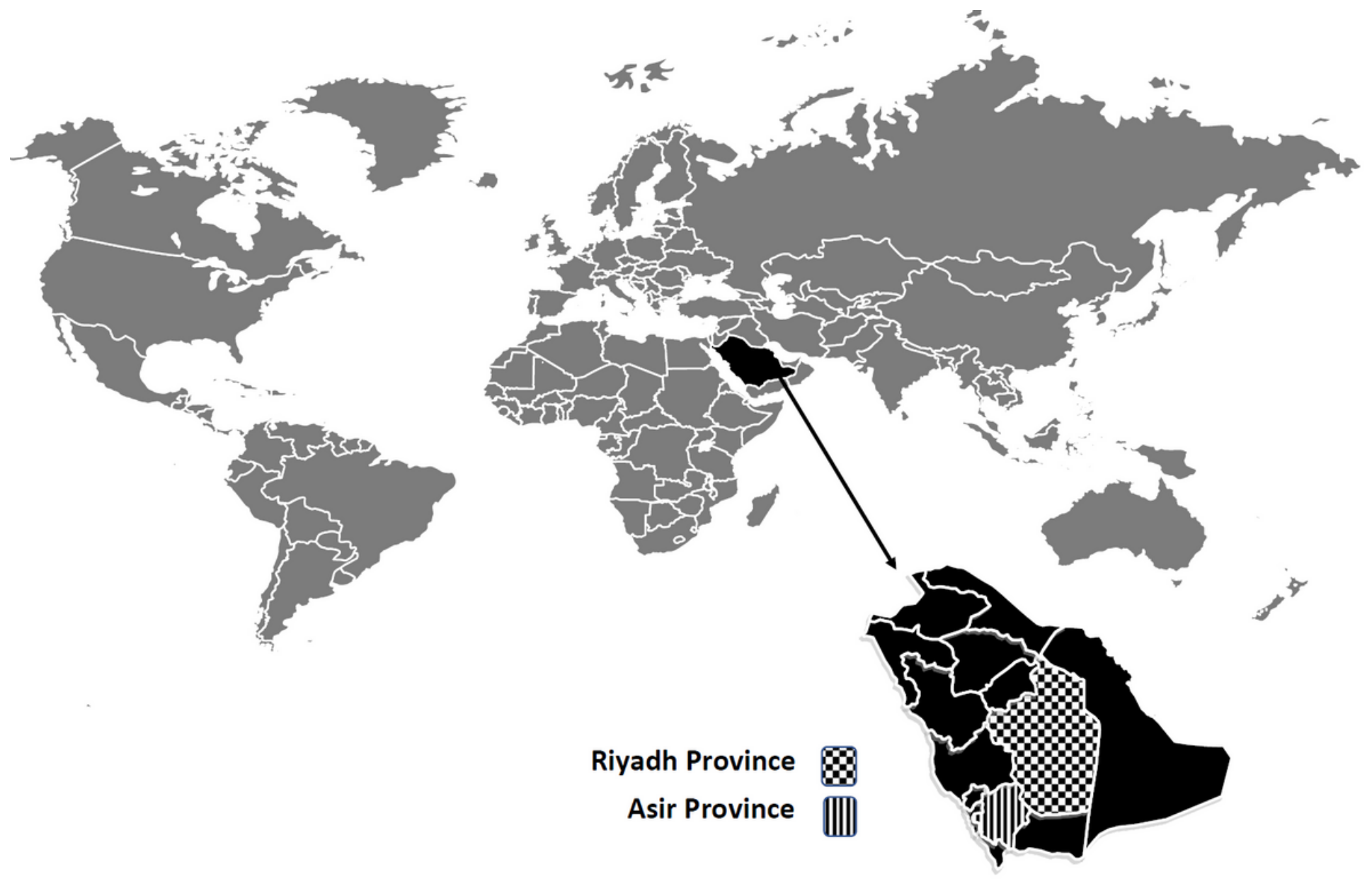

\section{Figure 1}


Map showing the study sites of Riyadh province and Asir province, Saudi Arabia. Note: The designations employed and the presentation of the material on this map do not imply the expression of any opinion whatsoever on the part of Research Square concerning the legal status of any country, territory, city or area or of its authorities, or concerning the delimitation of its frontiers or boundaries. This map has been provided by the authors.

\section{Supplementary Files}

This is a list of supplementary files associated with this preprint. Click to download.

- GraphicalAbstract.pdf

- SupplementaryTableS1.AnaemiaPanelResults.xlsx 